\title{
Representation of Power in The Panel of Judges's Speech at Semarang District Court's Trial: Sosiopragmatic Study
}

\author{
Eri Prihatmini ${ }^{1}$, Ida Zulaeha ${ }^{2}$, Rahayu Pristiwati ${ }^{3}$ \\ \{erryprihatmini@gmail.com¹, idazulaeha@mail.unnes.ac.id², \\ rahayupristiwati@mail.unnes.ac.id ${ }^{3}$ \} \\ Graduate School, Universitas Negeri Semarang, Indonesia ${ }^{1,2,3}$
}

\begin{abstract}
The language used by the Panel of Judges in court has its own uniqueness. The purpose of this study was to analyze the representation of power in the Panel of Judges' in the Semarang District Court's trial. This research uses sociopragmatic approach. The data used is a fragment of the Panel of Judges' speeches which allegedly contains pragmatic power and representation of power in it. Data collection was carried out by referring to proficient free technique, note-taking and recording techniques. Data analysis is done using the equivalent method. The data analysis technique used in this study is the determining element sorting technique. Representation of power analyzed using contextual methods. The results of the research show the power of the panel of judges' speeches in the trial representing power that comes from coercive, reward power, legitimate, expertise and referent power.
\end{abstract}

Keywords: representation of power, judge's speech act

\section{Introduction}

Enforcement of the Electronic Information and Transaction Law in Indonesia, cases have arisen that require linguists to be presented as expert witnesses. The role of linguists through the point of view of translation, sociolinguistics, and interpretation studies can be a good source of knowledge in reading a case. Unfortunately the study of language in the realm of court and people's understanding of the speech of the participants in the trial is still lacking. The language used by the Panel of Judges in the court is unique and involves many professions. They can communicates ideas that they understand well, but are not understood by society.

The concept of multidisciplinary pragmatics offers the possibility of pragmatics reaching meeting points with other disciplines [1]. The concept of multidisciplinary pragmatics is strengthened in the concept of critical pragmatics. The critical pragmatic approach is carried out because of empirical phenomena found that are not sufficiently studied only with a pragmatic approach [2]. In line with the concept of the new pragmatic study, the study of the representation of power in speech acts is an update that can be done in sociopragmatic studies.

In the perspective of functional or cultural pragmatics it is believed that speech acts are not a neutral one. The use of inappropriate speech acts can cause misunderstanding because of cultural differences between the origin of language and the user [3]. Speech acts are among 
the tools used to control the environment and also as a tool to adapt to the environment . Power can be demonstrated and applied through language. Implementation of power through language does not only occur in public spaces. The language used by parents to their children has a power relationship [4].

Power is an abstract concept but very influential on life [5]. It can also be defined as the power in society that makes action happen, so by researching it we can recognize who controls what and for whose sake. In contrast to this view, power is something that is neutral, not good and not bad even though in everyday life power is often given a sense of bad taste. Power is not a function in bondage, power is circular and never been monopolized by one center. Insufficient attention to the relationship between language and power has failed [6]. Previous research on language and law has shown that judges' speeches at court represent power [7].This shows that power relations spread to all levels of social existence so that their use can be found in all social life sites. In line with this opinion the practice of power in language is also thought to occur in court.

\section{Methods}

This study using a sociopragmatic approach as theoretical approach and qualitative approach also descriptive approach as methodological approach. The data of this study are fragments of the Panel of Judges' speeches at the trial which allegedly contained pragmatic power in the form of speech and representation of power within it. The research data collection uses the technique of referring skillfully, note-taking techniques and recording techniques. In analyzing the data the method used is the matching method. The data analysis technique used in this study is the determinant element technique. The determinant element technique is a basic technique in the matching method. Representation of power in the Panel of Judges at the trial in the Semarang District Court was analyzed using a contextual method.

\section{Results and Discussion}

\subsection{Coercive Power}

Someone reacts to this type of power due to fear of negative consequences that arise if they do not obey. Power of coercion is the power of punishment to others who are intended to modify the offender to be useful behavior. Class discourse analysis shows that the use of directive, firm, and expressive speech acts shows representation of power [8]. In line with this, the representation of power by the Judge Council is indicated by the utterances of meaningful directives of the command contained.

\section{CONTEXT : JUDGES CHECKING FIELD OF THE CHILDREN'S APPLICATION \\ Judge : "Yang diserahkan anda coba serahkan saya, saya cocokan apakah sama atau tidak." (1)}

Applicant : (submit the document to judge's table then return to his seat)

Judge : “Coba baca mulai 'Yang berdasarkan diatas'”" (2)

Applicant : (read out the application letter)

148/Pdt.P/2019/PNSmg. 
The judge's speech is a directive speech act. The three utterances are directive speeches that are intended by the speaker so that the speaking partner takes the actions mentioned in the speech. Meaningful speech commands represent the speaker's power. Meaningful utterances of orders are only spoken by the superior to the inferior and only apply in same direction. In conducting directive statements the inferior party tends to choose to use directive speech which means asking, suggesting or inviting. Based on its function, the three utterances function to request, urge and instruct, therefore the speech represents coercive power because the speech partner reacts to this type of power due to fear of negative consequences that arise when not obeying them.

\subsection{Reward Power}

Reward power occur when someone obeys the wishes or orders of others because by doing so he gets a positive advantage. Therefore, if there is someone who can give an award that in his view is something of value, then that person will have power over him, the award can take the form of anything he thinks is valuable.

Mixed code and code switching from Indonesian to Javanese sometimes occur in court. In Javanese there are different levels of vocabulary using according to the social context of the conversation. In connection with the concept of power vocabulary selection can also be a marker of power. The superior is more free to choose the level of vocabulary in his speech manifested in 'ngoko', or 'krama'. The inferior choose vocabulary levels that have a more polite meaning, are more subtle or have a more positive connotation manifest in 'krama madya' and 'krama inggil'. In the practice this is true otherwise, the superior gives an award to the inferior party so that the inferior party will feel valued and eventually the person will have power over him. In the utterance (3) it is indicated by the use of the word 'monggo' to offer.

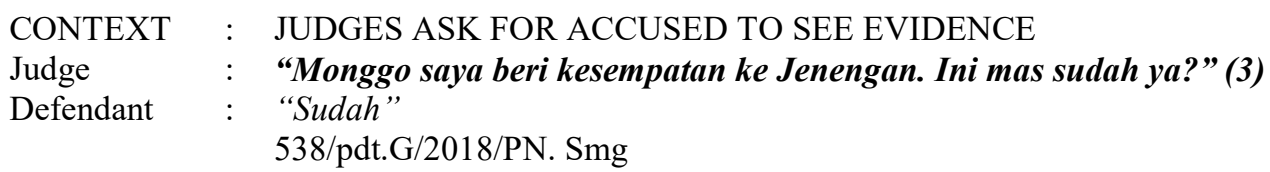

The representation of power is reflected in the choice of words and groups of words used [9]. There are several linguistic aspects that represent power [10]. Languages that show power and solidarity are shown in ways of calling, verb forms and vocabulary levels. A greeting is said to have a rule or meaning of power if the greeting is only used by the greeter or by the person who is addressed. In general, the greeting system is divided into five categories namely personal pronoun, proper names, titles, kinship terms and honorific greetings.

Panel of Judges' speech represented the power marked by the use of the greeting 'pengacara, terdakwa' to summon the parties to the trial. The greeting only applies one direction and does not apply otherwise. This was confirmed by the speech of a lawyer who answered the greeting of the judge using the greeting 'Yang Mulia'. That is a greeting of honorafic or greeting. Greetings of honorafic are used in the trial as a form of appreciation, respect, for the power of the judge as the leader of the session to the Panel of Judges as the leader of the session.

Relates to the power of appreciation, this is the opposite. Based on the speech (3) above the representation of power the award in the Panel of Judges' speech in the Semarang District Court is marked by calling indicated in the 'Jenengan' greeting used by the Judge. The judge 
as a superior party is free to use greetings to the speech partner, but in that speech the judge chooses to use the term 'Jenengan' as a form of appreciation for his speech partners so that the partner feels valued and does what the speaker wants. Therefore, it can be concluded that the Judge represents the power of appreciation in his speech.

\subsection{Legitimate Power}

Legitimate Power is a person's ability to influence others because of the position or position they have. Someone who has a higher level of power over a party whose position is lower. In this type of power the person who is dominated is obedient because he believes that the dominating person has the right to ask and the person who is dominated has the obligation to obey him.

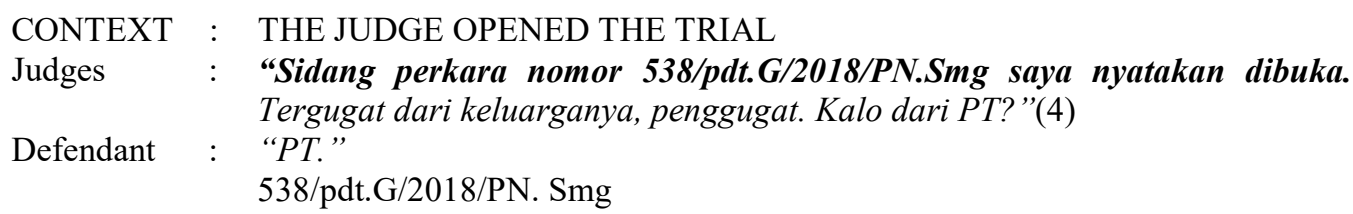

The Judge's speech (4) was a speech from the judge when opening the trial. The power of the position indicated in the speech opens the trial. The judge is a person who has a position as a state official and is in charge of the trial leader. The judge has the right to request and the person who is dominated has the obligation to comply. The judge has the duty to open, decide and close the proceedings. The authority is owned by the Judge based on his position. The power of judges has been given a place in the constitution of our country.

\subsection{Expert Power}

The expert power is the influence a person has as a result of the expertise of the knowledge someone has. Power of expertise is based on the perception or belief that the influence giver has relevant expertise or special knowledge that is not owned by the person affected.

\section{CONTEXT : THE JUDGE CONCLUDING THE DESCRIPTION OF THE WITNESS OF EXPERTS \\ Witness : "Iya. Deliknya pemalsuan" \\ Judge : "...Kita bicara pada normatif umumnya pengertian delik pemalsuan ini adalah diartikan terminologi memalsu adalah memalsukan dan membuat palsu. Kalau memalsukan itu sudah ada sebelumnya?" (5) 187/Pid.B/2019/PN Smg.}

Power of the interviewer can be demonstrated through how the interviewer controls and handles the interview process [11]. Judge likened the perceptions of all the participants in the hearing to the testimony of expert witnesses. The judge also consolidates the information obtained from expert witnesses to be emphasized again so that a red thread is found from all the information given by expert witnesses. Judge indicated that he had legal expertise and knew the regulations. The judge's speech directs the participants to understand what information is considered important and what information is considered and needed in the trial. Judge controls the topic of conversation so that it does not extend beyond the context. So 
that it can be concluded that the speech represents the power of Judges originating from the expert power.

\subsection{Referent Power}

Referent power is the power a person has because the personality style or behavior of the person concerned has charisma and is a role model. Referent power arises because of the admiration of others and the desire to be that person, both his attitude and behavior.

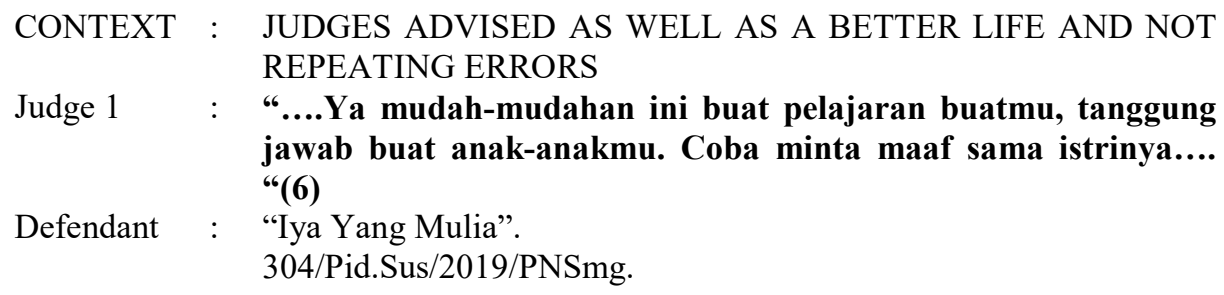

Judges in fragments (6) provide advice so that the defendant changes and has a better life. Judge's speech shows the personality style or behavior of people who have charisma and become role models. The defendant was affected by the personality as evidenced which stated that the defendant would change for the better. Therefore it can be concluded that the speech represents the power of referent.

\section{Conclusion}

The results of the research show the power of the panel of judges' speeches in the trial representing power that comes from coercive power, reward power, legitimate power, expert power and referent power. Hopefully the results of this study can be used as a reference in sociopragmatic research and expected to provide information and description of a speech society, specifically the description of speech acts in the environment of the Semarang District Court then can be used as additional references to facilitate building relationships and establishing cooperative relations in building communication between the general public and the legal community. 


\section{Reference}

[1] Cummings, Louise. Pragmatics: A Multidisciplinary Perspective. New. York: Oxford University Press Inc. (2007).

[2] Subagyo, P. Ari. "Pragmatik Kritis: Paduan Pragmatik Dengan Analisis Wacana Kritis". Linguistik Indonesia Copyright 2010 by Masyarakat Linguistik Indonesia. Tahun ke-28, No. 2, Agustus 2010, 177-187. (2010).

[3] Basra, Sri Meiweni \& Luthfiyatun Thoyyibah. "A Speech Act Analysis Of Teacher Talk in an Efl Classroom" . International Journal of Education. Vol. 10 No. 1, August 2017, pp. 73-81. Universitas Pendidikan Indonesia. (2017)

[4] Mudiono, Alif. "Tindak Ilokusi Bahasa Indonesia dalam Interaksi Keluarga”. Lingua. Vol. 11, No. 1, Maret 2014. Pusat Kajian Bahasa dan Budaya, Surakarta, Indonesia. (2014).

[5] Thomas, Linda dan Shan Wareing. Bahasa, Masyarakat \& Kekuasaan. Yogyakarta: Pustaka Pelajar. (2007).

[6] Wilmot, Natalie Victoria. "Language and the faces of power: A theoretical approach". International Journal of Cross Cultural Management 2017, Vol. 17(1) 85-100. (2017)

[7] Tracy, Karen \& Mary Caron. "How the Language Style of Small-Claims Court Judges Does Ideological Work". Journal of Language and Social Psychology. 2017, Vol. 36(3) 321 -342 (C. journals.sagepub.com/home/jls. (2017).

[8] Jumadi. "Function of Power in Class Discourse". Advances in Social Science, Education an Humanities Research, volume 263. International Conference of Languange, Literature, and Education (ICLLE 2018)

[9] Amir, Johar. Representasi Kekuasaan Dalam Tuturan Elit Politik Pascareformasi: Pilihan Kata dan Bentuk Gramatikal. Linguistik Indonesia, Februari 2013, 43-64. .(2013).

[10] Revita, Ike. "Bahasa dan Kekuasaan: Suatu Tinjauan Interaksi Antara Dosen Dan Mahasiswa Sastra Inggris di Dalam Kelas". Jurnal Arbitrer Universitas Andalas. VOL 1, NO 1 (2013).

[11] Mahmudah, Laela; Yesika Maya Ocktarani \& Yulia Mutmainnah. "Power Of Interviewer In "Kick Andy" On Metro Tv". Jurnal Lensa: Kajian Kebahasaan, Kesusastraan dan Budaya. Vol 3, No 1 (2013). 